\title{
Whose Identity Crisis is it Anyway? Questions of Cultural and National Identity in Two Novels by Second-Generation Maghrebians in France
}

\author{
Daphne McConnel \\ Benedictine College
}

$\mathrm{T}$ his article offers an examination of the role of cultural space and the question of national identity in two novels by second-generation immigrants of North African (Maghrebian) origin in France: Le Gone du Chaâba by Azouz Begag and Ils disent que je suis une Beurette by Soraya Nini. Of particular interest in both novels is the role of education. We will examine the function of education within the French republican tradition as the means by which a variety of individuals of varying backgrounds are transformed into "citizens" who share the same values; we must then also consider these protagonists' experience of education and whether it reflects these republican ideals. To what degree does school serve as a means of helping students of immigrant origin make the transition from the "foreign" cultural space of their parents to that of the French majority?

The question of cultural identity and the need for children of immigrants to negociate conflicting cultural spaces is central to recent studies of second-generation immigrant literature within France. A recurring theme in discussion of immigrant and diasporic literature is, of course, the sense of feeling "torn" between two cultures. The assumption is that the opposing values of these two cultures are constantly in conflict with each other, which in turn creates a problematic sense of identity for the children who must come to terms with their bi-cultural heritage. In fact, the sense of identity expressed in the novels considered here, and in most novels by the second-generation Maghrebians in France is far more complicated and ambiguous. Indeed there exist varying levels of cultural opposition within the corpus of novels written by second-generation Maghrebian authors in France. Hargreaves and McKinney propose that there are "at least three different types of cultural space [which are] open to France's post-colonial minorities":

... the dominant norms of the majority population, diasporic spaces associated with the country of origin and with other minority groups in France and elsewhere, and 
separatist enclaves detached from both of those fields. In practice, each of these seemingly distinct and internally unified spaces [is] far less clearly bounded than it may appear at first sight. ("Introduction"12)

The majority of novels by second-generation North Africans represent young, adolescent protagonists who must come to terms with the remnants of their parents' culture which are preserved within the host country, and which are represented by private home life, and the majority French culture which is represented in the public sphere, most specifically in the school. Significantly, "coming-of-age" narratives of identity that figure in most of the novels by second-generation North African immigrants are necessarily bound up in the question of "becoming" French. In many instances, one sees the role of the French administrative and educational system as intermediary between the country of origin and France, as well as between immigrant parents and their children. The pattern of opposition is thus one in which parents are anxious to preserve their cultural heritage and the schools are anxious to assimilate students into the cultural mainstream. However, the relationship between these two cultural spaces is not quite so clear.

It is true that North African immigrant parents are anxious to preserve their traditions; indeed, because many came as temporary migrant workers, they supposed that their stay in France was temporary. However, most of the parents in these novels strongly encourage academic success in their children. What we see in the novels considered here is that the host country, which is supposed to guarantee the assimilation of children of immigrants according to republican values, often fails to accomplish this goal. This failure is often perceived by the protagonists in their experience of the education system as deliberate; by excluding these children's cultural heritage from the classroom, they are to some degree excluding the children themselves from the educational process. These novels reveal a certain ambivalence in the expectations placed upon these children, on the part of the parents as well of the state. According to the post-colonial critic Homi Bhabha, this ambivalence is inherent to the concept of nation, and to the "growing recognition that the nation is more temporary and more transitory than we once believed" (1). This reading of two novels of second-generation Maghrebians and their critique of the educational process is largely based upon Bhabha's theories. We will consider here the place of culture in the concept of national identity, and the post-colonial construction of identity in the "third space," an intercultural space in which children of immigration find themselves. In interpreting Bhabha's theory of a "third space" in the context of second-generation Maghrebians in France, Martine Delvaux describes their identity as characterized by an "ambivalence" which simultaneously represents a sense of distancing and approaching, belonging and exclusion (683). In their essay on North-African culture in France, Ecarts d'identité, Azouz Begag and Abdellatif Chaouïte characterize immigrant culture as "rootless":

elle n'est ancrée nulle part, sinon dans des situations sociales et spatiales 
périphériques. C'est là toute leur nouveauté, celle d'apporter un angle de vue décentré par rapport à tout ce qui est dit sur les immigrés et la société française. (100)

This description by Begag and Chaouite ties in with Bhabha's theory to lend a perspective to the analysis that I propose here. Not content to be torn between two cultural identities, these authors construct their own cultural space which is not merely an "inbetween" space, but a unique identity which reflects their entire cultural universe. More importantly these authors seek to deconstruct the coherent "myth" of the French nation in order to reveal the ambiguities and ambivalence, and indeed the instability of French cultural identity. They seek to reveal what Bhabha describes as "the easily obscured but highly significant recesses of the national culture from which alternative constituencies may emerge" (3).

The first novel considered here is Le Gone du Chaâba by Azouz Begag. This autobiographical novel's title specifically indicates the cultural and geographic position of the young Azouz: the blending of Lyonnais slang (le gone = kid) with the Algerian slang (chaâba; the name of the "bidonville" - shantytown - where the novel begins) indicates that the protagonist is a child who lives in a North African shanty town in Lyon. The cultural spaces that appear in the novel consist of: the "Chaâba," which simultaneously represents the family's Algerian origins as well as their geographic and economic marginalization; an "HLM", inner-city housing project, where the family eventually moves; and the school, the site of the assimilation of immigrant children through the teaching of republican values, but also of the social and economic advancement of the entire family.

One interesting aspect of the novel is the depiction of the Chaâba in the beginning if the novel. It is simultaneously represented as a space of abject poverty but also of great cultural wealth and community. The sense of humor, freedom and richness that are present from the very beginning of the novel, even in such an impoverished environment, serve to legitimize the (legally and economically) "illegitimate" cultural space of the immigrant community. It places value on the traditions and relationships that are lost as the family eventually becomes further integrated into French society. The beginning of the novel recounts the daily routine of life in the Chaâba: women washing clothes; children going to school; a gang of children who harrass neighborhood prostitutes. However, this dose of "local color" or cultural flavor also takes on a more subversive tone: it reverses the apparent order of the two cultural spaces that the protagonist inhabits. The "Chaâba" which, from a majority French perspective, is a marginalized peripheral space, becomes the cultural center of the novel. Indeed, according to Begag and Chaouite, this recounting of the "daily routine" of immigrant cultures within France is an essential starting point in the creation of a narrative of identity: "L'histoire de leur vision du monde puise ses sources dans les périphéries de leur espace de vie quotidienne"(119). The school is the second cultural space which occurs in the novel. As discussed earlier, the school is intended as a 
means of assimilating young immigrants into the values of the dominant culture. However, Begag's narrative continually emphasizes that school serves to point out to immigrants their exclusion from the cultural majority, as the narrator describes in a "morality lesson" which serves to silence immigrant students through their difference:

Entre ce qu'il raconte et ce que je fais dans la rue, il peut couler un oued tout entier! Une discussion s'engage entre les élèves français et le maître. Ils lèvent tous le doigt pour prendre la parole, pour raconter leur expérience, pour montrer leur concordance morale avec la leçon d'aujourd'hui.

Nous, les Arabes de la classe, on a rien à dire...

Je sais bien que j'habite dans un bidonville de baraques en planches et en tôles ondulés, et que ce sont les pauvres qui vivent de cette manière (59).

Though this passage reveals the ambivalence of the assimilationist model of French education, a certain ambiguity is also implied in the narrator's words. If at first he seems to identify himself within the collectivity of "we Arabs"; he then goes explains his exclusion more in terms of class than of race: he is different from the French because of his poverty. However, he concludes that he must integrate into the majority culture by trying harder at school:

J'ai honte de mon ignorance. Depuis quelque mois, j'ai décidé de changer de peau. Je n'aime pas être avec les pauvres, les faibles de la classe. Je veux être dans les premières places du classement, comme les Français. (60)

Again, the complex layerings of the protagonists' sense of his own difference are clear: his desire to do well in school is to some degree expressed as a foresaking of his race ("changer de peau"), yet is still mixed in with questions of economic position; he doesn't want to be with poor/weak students. This raises the question of whether his desire to be "like the French" is limited to his scholarly ranking. Moreover, can one make the distinction between the two? Is it possible to separate his sense of racial and economic identity?

Despite this desire to do well in school, the young Azouz knows that his success will eventually lead to the loss of the cultural values and story/history of his family. He begins to recite with enthusiasm "Nous sommes tous descendants de Vercingétorix" (62) while recognizing that "Le maître a toujours raison. S'il dit que nous sommes tous des descendants des Gaulois, c'est qu'il a raison, et tant pis si chez moi nous n'avons pas tous les mêmes moustaches" (62)

One cannot help noticing the irony of this 'recognition'; one has the distinct impression that the narrator knows how to play his role and it is clear that he's not buying into the whole myth. Moreover, one wonders if the inclusion of the obligatory recitation of "Nos ancêtres les Gaulois" isn't a further undermining of the myth of a coherent French national 
identity. After all, the great hero of French nationalism did defend the country against Roman invasion, but ultimately lost. Thus, the author employs the very rhetoric of French nationalism to point out France's long-existing and oft-forgotten multiculturalism.

The narrator's resolve to become a better student by becoming "more French" continues to be fraught with ambivalence. He decides that "A partir d'aujourd'hui, terminé l'Arabe de la classe" (62), a resolution whereby he decides to distance himself from his neighborhood friends, his own cultural identity, and his language. However, as he becomes more integrated into the educational system, the narrator allows himself later to proclaim during a lesson on hygiene that one bathes with "un chritte et une kaissa" (98) (the Arabic terms for a loofah and a bathmitt). Because he is a good student, his teacher asks about the meaning of the words and tells him "C'est bien de nous avoir appris ça" (99). Thus scholarly success ultimately permits a subversion of the hegemony of the school system; the insertion of Arabic into the classroom corresponds to the text that Begag will later write. His integration of Arabic terms into his novel, his recreation of the spoken Maghrebian accent and dialect in written French, and his recreation of the 'illegitimate' cultural space of his childhood into popular French literature are all representations of his own cultural identity that simultaneously serve as emblems of the subversion of French hegemony. These linguistic and narrative strategies of immigrant literature are described by Delvaux as "un procédé stylistique dont l'effet consiste à décentraliser la notion de l'identité nationale" (681). This strategy occurs on a metatextual level in the example of a composition topic that the young Azouz is assigned, where he must describe a day in the country. The narrator admits "Je ne peux pas lui parler du Chaâba, mais je vais faire comme si c'était la campagne, celle qu'il imagine" 67). The Chaâba that he cannot write about for school is the same cultural space that figures as the novel's point of departure; he subverts the silencing power of the educational system by representing his family's "silenced" culture in his own novel.

Despite the subversive potential of scholarly success, there exists within the text a correspondance between Azouz' success and his social integration and the desintegration of the family's cultural space. As the family moves from the Chaâba to an HLM, its community connections and many of their traditions are lost. In describing the cultural space that immigrants create for themselves, Begag and Chaouite contend that their participation in the new culture is above all a situation of 'insularisation', and that immigrants try to create "un espace intime qui tente de reproduire le style de vie premier; le rapport à l'espace des enfants est évidemment tout autre" (47). The cultural space of the Chaâba represents a sort of innocence and freedom before the child must integrate into the system of power. The space is defined by the community of those who inhabit it; once the other families leave the Chaâba, it becomes an empty space which has no value. Azouz' father, who holds power within the immigrant community as "propriétaire" of the Chaâba, owns nothing.

Visage de marbre, mal rasé, les yeux brillants, il ne laissa paraître aucun signe de 
faiblesse depuis que le Chaâba est mort. Il n'y a plus de Chaâba, il y a une maison désormais. Sa maison. Bouzid a mal saisi le déroulement de l'histoire. Il ne se pose pas la question de savoir pourquoi les gens ont fuit son paradis. ... Un remblai de matériaux de construction pour bidonville! Voilà ce qu'il reste du Chaâba. (149)

The father's power is eventually replaced by that of the state; when the family moves into an HLM in town, social systems begin to have more influence on the narrator than his family. This move represents what Michel Laronde describes as

ce glissement volontaire de l'immigré vers un ancrage géographique à l'intérieur du système de pouvoir [qui est] l'occasion de la première coupure entre la génération immigrée et celle des enfants nés en bidonville mais élevés en HLM. (101)

Like the paradise of the Chaâba which is ultimately lost, the title of another of Begag's novels, Béni ou le paradis privé, also refers to the protagonist's lost cultural heritage; the word 'privé' refers to the "private" culture of the immigrant family, and also implies that that culture is denied him because there is no place for it in the public sector. The same cultural gap between children of immigrants and their parents is also represented by the narrator who falls in love with a young French girl (named France!). Though Béni's parents are proud of his success in school, he acknowledges that

s'ils savaient aussi que je suis tombé amoureux fou de France dès la première heure de cours, mon père m'expédierait illico au bled et ma mère, comme d'habitude, se déchirerait les joues, s'arracherait les cheveux, avant d'aller consulter un marabout (44)

The narrator's distancing and alienation from his parents' cultural heritage is portrayed with an ironic distance as he describes their reaction with the embarrassement typical of an adolescent ashamed of his family's "difference". The protagonist in Le Gone du Chaâba plays more ambiguously on his difference and that of his parents. When students mistake him for a Jew, he goes along with the role. However, the "gaze" or "appearance" of his looks which allow him to deny his heritage also betray him in the end when his mother comes to get him from school, an event which signals the meeting of the two cultural spaces which had remained separated until this point:

Je descendais l'escalier qui débouche directement sur le trottoir de la rue, les deux compatriotes juifs à mes côtés. Plusiers mamans attendaient leur gones. Soudain, une vision insupportable boucha le cadre de la porte. Là, sur le trottoir, évidente au milieu des autres femmes, le binouar tombant jusqu'aux chevilles, les cheveux cachés dans un foulard vert, le tatouage du front encore plus apparent qu'à l'accoutumée: Emma. Impossible de faire croire qu'elle est juive et encore moins 
française. (190)

The visible presence of his mother reminds the narrator of his own identity and his own connection with his cultural heritage, but he also sees his mother from a distanced point of view, observing her difference from the other women. Her physical presence in front of the school reveals his simultaneous connection with and alienation from both cultural environments. The novel ends on similarly ambiguous terms with the narrator's family being forced to move from their apartment into a newer HLM. The last two lines of the novel reveal the family suspended in a cultural no-man's-land. When the housing agent asks Begag's father "Alors, quand c'est que vous repartez dans votre pays?" (241), the father replies " - Hou là là!. . . Ci Allah qui dicide ça. Bi titre, j'va bartir l'anni brouchaine, bi titre li mois brouchain". This conversation reveals the reluctance on the part of the French as well as the immigrant generation to accept their permanence within France; all this while it is apparent that the family is being further and more permanently integrated into the administrative system. The open-ended narrative would seem to imply that the family's future is still in question, but we know that it is not. However, the narrative has come full-circle in a sense, with the narrator recreating and preserving his family's traditions in the Chaâba in the beginning of the novel and with his resolve to still tell his father's story (and fondly and humorously recreate his dialect) at the end. $\mathrm{He}$ creates a technique that allows him to integrate all aspects of his cultural identity in to a coherent narrative structure

As Begag's protagonist exploits the ambiguities of his cultural identity in order to establish and understand his own place, similar narrative strategies are at work in Soraya Nini's heavily autobiographical novel, Ils disent que je suis une Beurette. The title implies a narrator who refuses in a sense to accept a label that is given to her by the French, mainly by the media. The novel begins from the point of view of Samia, an narrator who claims the cultural space of the world she inhabits, a suburban HLM. The novel is thus situated in a time frame that picks up where Begag's novel leaves off. The novel begins with the sentence "Je suis née au Paradis [ a housing project] et il paraît que je suis une 'beurette', ça veut dire une enfant d'immigrés" (90). This opening sentence identifies the narrator's claim to French national identity by birth; it simultaneously signals that she is viewed by the French as a foreigner. Like Azouz, the narrator in this novel begins by describing her daily life. Unlike the previous novel, it is apparent in this novel that the narrator seeks to specifically address negative pre-conceived stereotypes of the world she inhabits. Her explanation of the term 'beurette' implies that this term means nothing to her and signals her awareness of labels that others place upon her. Like Begag, the narrator finds herself obligated to justify her identity as French and to refuse the foreignness which is imposed upon her.

The novel criticizes the role of media who exaggerate the problems of housing projects. A journalist who comes to report on the residents of the projects appears more interested in the abstract idea of this life, rather than its banal reality. This attitude, along with the 
word "beurette" intimates a tendancy to attribute a certain exoticism to children of immigrants; if they are recognized at all . The narrator, Samia, defines herself as an object of the gaze from the beginning of her first conversation with the journalist:

— Bonjour! Tu habites ici? — Oui, bonjour! Pourquoi, ça ne se voit pas?

- Ben oui, moi quand je vous ai vus arriver, j'ai tout de suite remarqué que vous n'habitiez pas au Paradis. Ceux qui habitent dehors, ils le voient tout de suite, eux aussi, qu'on vient de la cité (9)

This introductory dialogue sets up right away the decentering of cultural space. For the narrator, the peripheral space of "Paradis" is the cultural center of the novel, and those who live "within" are distinguished from those who live "outside". Nevertheless, the journalist's report establishes the media/journalists/the French as those who watch, and who interpret the existence of those who live in the projects.

Nous sommes venus faire un reportage pour la télévision. Nous allons filmer la cité pour montrer ce que vous faites, comment vous vivez. Mais nous avons besoin d'un guide, tu veux bien nous conduire? (10)

It is clear that the reporter has already determined what she will show; she doesn't say she's come to learn or to ask about people's lives. Rather, she intends to use the power of the gaze to recreate the relationship already established in her own mind between French subject and immigrant object. This relationship reinforces the idea of the immigrant as "other"; as stated by Gerard Noiriel: "An immigrant is, above all, to paraphrase Jean-Paul Sartre, someone whom others regard as an immigrant" (xxvi). Thus, the narrator must affirm her own presence and identity, and tell her own story, by addressing this gaze.

However, this report is never broadcast, and the narrator - like the reader, concludes that those responsible must have decided that her life story isn't worth telling:

Peut-être que son reportage ne lui a pas plu? Pourtant, c'était bien, ce jourlà...Remarque, maintenant que j'y pense, peut-être qu'à la télé, ils veulent pas montrer où on habite. Je les comprends un peu, c'est tellement moche. Nous les premiers, je suis sûre qu'on n'aurait pas regardé, c'est pas la peine, on connaît déjà.

Nini employs here a diagetical strategy similar to that of Begag; as he used the novel to represent the aspects of his parents' culture that he couldn't write about in school, she uses her own text to tell the story that mainstream media would not represent. This "story" is mainly concerned with the banal daily events of life in a housing project; in particular, conflict between residents, conflict within the family, and the narrator's difficulties at school. 
This novel also represents to failure of the educational system to adequately integrate children of immigrants, as well as disadvantaged children in general, into the mainstream. Early in the novel, immediately after the incident with the television report, Samia begins to describe the alienation that she experiences at school:

Un jour, à l'école primaire, mon institutrice m'a demandé le métier de mes parents et des grands de la famille..... Qu'est-ce qu'elle me branche celle-là avec ses questions? En plus, elle n'arrête pas de me commenter ce que je dis, ça m'énerve, elle me fait honte devant les autres. (18-19)

Samia's situation is all the more tragic that she isn't as academically gifted as Azouz. The critique of the school system's failure to integrate children is more serious here. Put into a class of 'débiles', worthless students, the narrator dares to ask the teacher why they don't learn more challenging lessons; the teacher, rather than encourage her, throws her foreignness or difference back into her face:

Vas-y, prends ma place au bureau et parle-nous de l'Algérie. C'est bien ton pays? ....Mais moi, j'arrive plus à parler, je prends la règle dans mes mains pour m'occuper. Ils attendent tous que je dise quelque chose, mais qu'est-ce que je peux dire sur l'Algérie? J'y ai jamais mis les pieds et puis, de toute façon, je ne peux pas parler, j'ai une grosse boule dans la gorge.

_Allez, regagne ta place maintenant. Et j'espère qu'on ne t'entendra plus! (25-26)

Like the journalist, the teacher makes inaccurate assumptions about the cultural/geographic space that the protagonist occupies. The narrative seeks to address both of these misrepresentations - the inaccuracies portrayed in the media and the failures of the educational system - through the narrator's representation of her own life and her overcoming of her poor education in order to become a social worker. When Samia becomes involved with a teacher who encourages her to study social work, this allows her first a way to get out of the project, and to ultimately return to it on her own terms. The novel ends with a rap performance by Samia's brother, Foued, which includes again a critique of negative images of second-generation immigrants represented in the media:

- Je vais te dire ce qu'est un BEUR. . . . On me fait croire que je suis important / Parce qu'on m'appelle BEUR, / Dans les journaux, à la télé, partout! . . . Je suis coincé et de l'autre côté, je les regarde, / Je les écoute me raconter mon histoire qui finit mal! (248-249).

This critique at the end of the novel comes back to the critique of mainstream journalism with which the novel begins. The rap performance seizes on the media's appropriation and subsequent labeling of the term "beur" just as the novel rejects such 
interpretations and lets Samia tell her own story. Such narrative strategies are inherently ambivalent: just as the characters simultaneous seize upon and reject the term "beur", the novel's title does the same. The rap performance in the end raises the question of whether rap and novels are the best alternative forums in which the second-generation of the Maghrebian immigrants in France can counteract the silencing effect of mainstream media and the educational system. Is it sufficient to move representation to such peripheral forums? Will this decentering be a means of disrupting the idea of a coherent unified French culture?

As stated earlier, it not sufficient to say that these authors are caught "in-between" two cultures. Both cultural influences contribute to their sense of identity, but either one alone is insufficient, incomplete and ambivalent. The French culture that demands their assimilation simultaneously rejects them. Parents demand success but are devastated when their children lose to some degree their cultural heritage. By questioning the authority of the school system and the mainstream media, these authors point out the ambivalence inherent in the concept of a French national identity that is refused to them. They justify these characters' right to a French identity on their own terms and their narratives address what Noiriel describes as "the denial of memory" which is a "key epistemological problem" in contemporary France (1). The questions of cultural identity raised in these novels demonstrate Homi Bhabha's theory of the "locality of national culture" which is neither unified nor unitary in relation to itself, nor must it be seen simply as 'other' in relation to what is outside or beyond it. The boundary is Janus-faced and the problem of outside/inside must always itself be a process of hybridity. ... What emerges as an effect of such 'incomplete signification' is a turning of boundaries and limits into the in-between spaces through which the meanings of cultural and political authority are negociated. (4)

Both novels exploit the silencing potential of nationalist discourse and expose the inevitable gaps and ambiguities in such unitary concepts of identity in order to create a space for the expression of the protagonists' own realities.

\section{Bibliography}

Begag, Azouz. Le Gone du Chaâba. Paris: Seuil, 1986.

. Béni ou le paradis privé. Paris: Seuil, 1989. and Abdellatif Chaouïte. Ecarts d'identité. Paris: Seuil, 1990.

Bhabha, Homi. "Introduction: Narrating the Nation." Nation and Narration. Ed. Homi K. Bhabha. London: Routledge, 1990. 1-7.

Delvaux, Martine. "L'Ironie du sort: le tiers espace de la littérature beure." The French Review 68:4 March 1995: 681-93. 
Elia, Nadia. "In the Making: Beur Fiction and Identity Construction." World Literature Today 7:1 Winter 1997: 47-54.

Hargreaves, Alec G. Voices from the North African Community in France: Immigration and Identity in Beur Fiction. New York: Berg, 1991.

and Mark McKinney. "Introduction." Post-Colonial Cultures in France. Ed. Alec G. Hargreaves and Mark McKinney. London: Routledge, 1997. 1-25.

Laronde, Michel. Autour du roman beur: immigration et identité. Paris: L'Harmattan, 1993.

Nini, Soraya. Ils disent que je suis une beurette. Paris: Fixot, 1993.

Noiriel, Gérard. The French Melting Pot: Immigration, Citizenship and National Identity. Minneapolis: U of Minnesota P, 1996. 